\title{
AN AWKWARD, UNEASY (DE)COLONIALITY HIGHER EDUCATION AND KNOWLEDGE OTHERWISE
}

\author{
André Keet \\ Nelson Mandela Metropolitan University (Research Associate) \\ University of the Free State \\ KeetA@ufs.ac.za
}

Sahar D. Sattarzadeh

University of the Free State

SattarzadehSD@ufs.ac.za

\section{Anne Munene}

University of the Free State

MuneneAW@ufs.ac.za

\section{PART ONE: ANDRÉ KEET}

Is it appropriate to speak of an "after" in our reflections on the 2015-2016 student protests on the South African higher education landscape? Is it an "after"? If so, of what? What will this "after" designate? How can this "after" be thought of? And what does this "after" say about ourselves and our society? What forms of praxes are demanded in the "after"? What possibilities have been opened up? These questions occupy the musings of this editorial note. To manage the arguments, let us agree - for expediency and nothing more - to name the 2015-2016 student protests an "uprising". Let us also concur to name it the "\#MustFall uprising" with sub-episodes, pre-episodes and episodes to come. Other reflections will locate and assign it differently, as it should be. Let us further go along with commentators, scholars and activists and think of this uprising as the most wide-ranging expression of discontent within and with higher education post-1994 and with the South African democratic project in general.

This editorial note is speculative-analytical. Its prose is purposefully exaggerated, rough and provocative; my apologies. This may allow us to go behind the appearances of what we produce as truths. Though this note contains broad assertions to invite

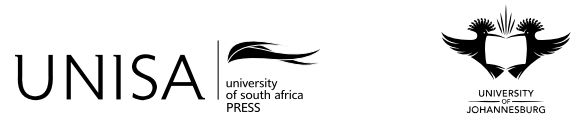


discussion and debate, I am well aware of productive social justice work on the education research landscape. These ruminations also do not discount the massive progress made in education since 1994; this is acknowledged and much has been written about it already. As much a cocktail of conjectures about the academy and its social actors, this note, needless to say, is also a gaze towards my own historical production within the academy: a sort of self-reflection on self-constitution as complicity. Before I get to the gist of my observations, let me do a quick detour to deal with some possible distractions and detractions.

First, the link between the student protests and the nature and dynamics of our national politics is acknowledged, along with all the socio-economic and politicocultural challenges and analysis it tows along. I will not dwell upon them here. Second, I do not agree with the "very limited violence" - in whatever way "violence" is defined - that attended the protests. Violence is not a prerequisite for radicalism and militancy in the current South African context. Third, I am not engaging with the question of fractures and solidarities within the \#MustFall uprising, as I am not qualified to do so, and it is not the purpose of this editorial in any case. Fourth, though it is clear that the \#MustFall uprising is linked with global popular and international student protests that express disillusionment with the world-wide project of democracy, human rights and social justice, it is not a subject that I am exploring here. Fifth, the \#MustFall uprising certainly had negative effects on teaching and learning and on the universities' capacity to execute their mandates; it also had consequences and after-effects for all agents within the sector, including students, academics, communities, university management and state actors. This topic is not touched upon in this note. Lastly, the \#MustFall uprising $\mathrm{had} / \mathrm{has}$ positive consequences, and, when all is said and done and delayered, there is a legitimate social justice project with significant and rational political content at the heart of the \#MustFall uprising. This, social justice in the language of decoloniality, and the risk of its discursive displacement and "metaphorisation", is the focus of this editorial's conjectures.

Let me now turn to the arguments I would like to put on the table. We may be located within the \#MustFall uprising in the midst of the "after" of its first episode. This "after" must of necessity author and authorise an out-of-jointness - a sort of placeholder for a disrupted "something". When thought of in the idiom of out-of-jointness, the "after" is a time and place where our receivable categories for making sense of our academic reality are questioned; the "after" becomes an authentic realisation that we do not share the same linguistic universe amongst ourselves and as individuals. Neither do we share it as groups of social actors in universities and the broader polity. Out-ofjointness is meant to prolong the condition of a disrupted something, an as education. This orientation is unfamiliar to the academy, I think. Rather, the default position is to quickly reduce the reality of agonistic vocabularies into agreements as a necessity to make social institutions such as universities function (see Boltanski 2013, 55). Is it not possible that what this "after" highlights, then, about ourselves and our society, is 
an aversion to a radical uncertainty within which the reproductive machineries of the university are hidden in plain sight? That is, are the procedures of reproduction not simply concealed as aversion? Thus, things have to stay the same, and when it comes to our praxes, the "after" has simply given us a new name with which to tag the old; decolonisation talk now simulates transformation.

To be honest, however, we have been here before in post-1994 South Africa: the emergence of an assortment and display of educational initiatives under a "new transformative trope". They are occurring in waves. We experienced an academic frenzy on the pre- and post-1994 condition: reconstruction and development, "racial" and other integrations, "rainbowism", social cohesion, Ubuntu and so on. This fever was folded into an unthinking proliferation of a transitional justice industry with questionable "models" of forgiveness and reconciliation that emerged within and outside the university. Much needed and productive in the post-1994 South Africa of the 1990s, there is not something intrinsically wrong with the reconciliation discourse. Rather, the question is what form of politico-cultural regimes and psycho-social registers are presupposed in this discourse to justify the perversion of the material? Is it not possible to perceive these regimes and registers not as justice-making devices, but as machineries of neoliberalism inscription?

On the broader landscape of the "disciplines", law, the arts, humanities and the "social sciences", together with education and "natural sciences and health sciences" all clamour for a space in the "scholarly transformation sun"; a sort of academic innocence-making and redemption project. Studies on human rights and transformative constitutionalism that masqueraded as critical social theory and praxes followed; and studies on and conceptions of deliberative, participatory, consensus-seeking democracies began to steer both academic and political praxes. Human rights forgot that its task is to hold law to justice. Instead, the law collapsed human rights into itself and now lacks a mirror of justice. The Africanisation theme from time to time reared its head. Education, the definitive non-discipline, had a field day. Profoundly affected by the general weaknesses of the humanities and social sciences, it followed any direction, fad or fantasy. Anything goes.

Discounting the role of justification that obeys a certain scholarly rigour, education research subsumed itself in a ready-made paradigm of rights and transformative constitutionalism as its reference point. It became commonplace for research rationales to take the 1996 Constitution and South Africa's post-1994 policy regime as its starting point. They kick off more or less like this: "since the advent of the new South Africa ...", "the South African Constitution states ...", or "policy so and so declares ...". There is no need for further, rigorous justification, or normative clarification. From here, it was only a short jump for policy-against-implementation studies to grab and imprison our imaginations, an easy measuring of the distance between policy framings and social reality where "implementation" and its agents always emerge as the malefactors. Action research and other reflexive research orientations conservatised themselves into a 
specialised industry, leaving behind their nuptial agreements with the critical pedagogy and theory of the 1980s and 1990s. Using this very large opening doorway, studies on "integration" and "inclusion" took their chance, and scholarship on identity took its place on the educational research stage. Post-colonial and post-structuralist studies became major players on the South African educational scene, while preservationist academic thought more or less maintained a firm foothold. Believe it or not, some research is still littered with drops and chunks of fundamental pedagogy and Christian National Education. "Pedagogies" boomed - a pedagogy of this, a pedagogy of that. We snatched concepts encountered in some or other "post"-thinker and created "pedagogies", did research on them and published. Amidst all these manoeuvres, education research has empirically been defined as being predominantly small-scale and of little value. ${ }^{1}$ It seems not much has changed since the release of these reports a decade or so ago.

Like all research entangled with economic, cultural and political networks, education research creates its own industries; within which I am located and steered myself. These industries, in turn, generate and exploit fads and trends as part of the circulation of commodities, functioning as a market. In this market today, decolonisation is the latest in thing; its lure and seduction are unmistaken. So, here we are again. A display of initiatives under the rubric of the decolonial are protruding on the higher education landscape: workshops, colloquia, conferences, lectures, special journal editions, talks and so on are trending. Some academic and university-based work are giving themselves a decolonial twist, slipping in a "right" word and "concept" here and there. For others, we have been decolonial all along; it is nothing new. And for some, it is simply a "turn of expression" which has very little to do with how we see ourselves doing academic work or living our academic lives. We do not have an interest in what decoloniality may actually mean nor are we concerned about what kind of academic and political citizenship it presupposes.

The decolonial discourse is a welcome development; but we need to caution ourselves on a few scores. It seems that the decolonial will struggle to become a praxis and may instead remain a form of rhetoric - not because it does not have the resources or imaginative capacities, but because the social structure of the academy will disallow it to become a productive reference point. The treatment and travels of the concept of higher education transformation since 1996 in South Africa gives one a glimpse of what may happen to the decolonial. Repurposed to fit both the onset of a special brand of university neoliberalism and managerialism, transformation suffocated. Used by conservatives, racists, sexists, bigots, dogmatists, sectarianists, chauvinists, raceessentialists, fundamentalists and progressives alike, transformation could literally serve any intention assigned to it. One can thus argue that the decolonial call is not blind to the massive policy-induced changes on the higher education landscape. It

1 See "Status Quo Study of Education Research in South Africa. Education and the Challenges for Change 2003-2006" (National Research Foundation 2009) and Audit and Interpretative Analysis of Education Research in South Africa: What Have We Learnt? (Deacon, Osman and Buchler 2009). 
simply could not tolerate that which imitates transformation and wears its cloak, and this is true for all the universities in the system. When a dedicated department for higher education and training came into being in 2009, it was almost too late to rescue the "idea" of transformation which has already been pummelled into submission to serve the reproductive logic of the system at the conservative end of the institutional spectrum. The medium- and long-term programmes from the department on the transformation of the academy and other spheres of the sector which are now in place, will take time to bear fruit.

There are ways to make the present decolonial rhetoric find practical expression within the academy, and to safeguard it as a productive angle to engage with the transformation of our universities. For starters we have to collaborate with serious thinkers (students included) on the decolonial. The Africa Decolonial Research Network (ADERN) at the University of South Africa (UNISA) coordinated by Sabelo Ndlovu-Gatsheni is one such example. There are others. This of course will bring us in conversation with the considerable intellectual history associated with the Latin American decoloniality network and Caribbean political and social theoretical thought. An engagement with Africana Studies, Chicana/o Studies, Asian Studies, and so on will inevitably follow; and a dialogue with Africana Critical Theory, feminist theory, queer theory, critical race theory, etc. will be regarded as overdue. A sort of colloquy, buzz group of critical theories in its broadest sense will take shape. In this colloquium of praxes, we will explore the power mechanics of institutions, work at its centre and its margins, and traverse the boundaries with a commitment to build socially just orientations within our universities.

When Marx $(1844,12)$ defined critical theory as the "self-clarification of the struggles and wishes of the age", he called for a "ruthless criticism of everything existing" (1844, 13), but not to set up "any dogmatic flag". This critique, obviously, must start from self-criticism - to be critical of the critical. Thus, if we are serious about renewing our cultural traditions and transforming our social practices, the academy, I, must be careful not to convert the students' call for a decolonial education into a scholarly cult. Rather we should, with our students and through critique, contribute to the self-clarification of the struggles within our universities. And this would include critical categories of self-understanding about what we actually do and the consequences of our types of academic citizenships to better see our complicity in the systemic anchoring of socioeconomic inequalities and discriminations of all sorts. This would mean an everyday resistance to being re-interpellated into techno-capitalist ontologies as a form of selfimprisonment with benefits. Above all, we will have to be willing to be de-disciplined and re-disciplined, both in relation to how we "are" our disciplines, and our proclivity to administer unfair discipline and judgement via the knowledges with which we work. We may then disclose to ourselves, that, with exceptions, education research and praxes borrow their political ontology not from decoloniality, but from the everyday epistemic fascisms that make knowledge the property of racism, sexism, etc. Knowledge belongs 
to racism (Keet 2016) and other discriminations; and racism, in the university, speaks through the megaphone of the knowledge-power-authority triad.

The project of decolonising knowledge involves admitting and then working against our "Coloniality of Being" (Maldonado-Torres 2007) and with every movement, dislodging, little by little, racism's hold over knowledge, to work against the epistemic injustices of all knowledge formations (Keet 2014). Ours is not the task of generating new dogmas, to heed Marx's caution. Rather, and the decoloniality and Africana scholarly scene is awash with this logic, we should struggle towards epistemic freedom.

I borrowed and tweaked the title of this editorial note from Mignolo's $(D e)$ Coloniality and Uneasy (Post) Colonialism (2013) to denote an uneasiness, and awkwardness in our present discourse on higher education in South Africa. I am, to a large extend, struggling with my own "awkwardness", my own complicity, my historical production of self. For instance: why are we, the academics, not called out as we should be? Why do we not readily allow ourselves to be confronted? Why did the decolonial impetus not start with us? Where was/is philosophy, sociology, health sciences, law, etc.? We must, I think, ponder why we have exchanged the decolonial project, which had high currency on the African continent since the late 1950s, for a transformative constitutionalism and reconciliation project post 1994, very seldom considering that the two should go together; a sort of decolonial reconciliation programme. Thus we left the coloniality of knowledge untouched, fated to grasp transformation only in the vocabulary of the coloniality of the disciplines and their knowledges, as knowledge disciplinarians ourselves. We now have an uneasy (de)coloniality; a form of praxes required in the now whose resources in the South African space have been sublimated. It is an awkward, inept (de)coloniality, because it is unproductively steered through interpretive schemes and scholarly orientations that have always sneered at it. Nonetheless, let us see this uneasiness and awkwardness both as a space of education and as the affective reminder of our complicity. It was Althusser, in The Future Lasts a Long Time (1992), who reminded us that if one is deprived of the consequences of one's actions, if we rob ourselves of our complicity, a non-agential spectral existence is the best we can hope for. Though, we can hoodwink ourselves to believe otherwise through moral disengagement and maintain our sense as moral agents whilst generating social injustices.

The pragmatics of decoloniality is immanently possible in what we see now in the academy and how we define the purpose and character of universities: as massive institutions that require dexterous management and scholarly approaches. In this, we have to acknowledge the role played by the Department of Higher Education and Training, academics, students, workers and the top managers of universities. None of these are perfect. But what is infinitely clear is that a few have to stand proxy for the lack of knowledge transformations within our universities over the past two decades. That is, operating within the context of academic freedom and scholarly autonomy, the academy should have been at the forefront of knowledge and curriculum renewals, so as to moderate, as impossible as it may seem in the age of neoliberalism, the interplay 
between the cultural and material conditions that gave rise to student discontent. Not because the discontent has to be managed. Rather, such renewals should be part of how we constitute ourselves as academics in the first place. It is the right thing to do. Returning to the pragmatics of decolonising knowledge: the global examples on offer range from the hard sciences to humanities as anyone with even a remote interest in the political economy of science will know. Talking about "knowledges otherwise", "an other thought, an other knowledge are indeed possible" (Escobar 2007, 179).

These arguments, amidst the new frenzy of the decolonial discourse, are an unpretentious caution not to make decolonisation a metaphor - to safeguard its radical potential. In this, we will not agree with what it may mean, or how it can be performed or how it ties into the higher education transformation project. The best starting point is always one's own categories of self-understanding. What is it that I do and don't do that generate discontent with the social justice transformation project of the university? When Tuck and Yang $(2012,1)$ wrote "Decolonization Is Not a Metaphor", they were worried by the "easy adoption of decolonizing discourse by educational advocacy and scholarship" for non-social justice purposes or status-quo work. Let this not be a charge levelled at us in years to come. We are in an "after" worthy of authentic self-reflection on both our "complicity" and historical production as academics.

\section{PART TWO: SAHAR D. SATTARZADEH AND ANNE MUNENE}

One could purport that this issue of Education as Change includes articles that delve into the authors' diverse understandings of and approaches to the decolonial, especially within education reflecting on the "after" moment, be it "post-1994", post-conflict, post-migration and so on in South Africa or elsewhere. There are nine articles and one book review in this issue that explore "decolonial" concepts and practices of inclusion, marginalisation and invisibility, agency and application of the critical within formalised education structures at the primary, secondary and postsecondary levels. The articles address issues relating to emigration and migration, language, curriculum, discrimination, among others. In spite of the differences between them, there are also evident similarities that manifest in how the authors analyse cases from Portugal, South Korea, Spain, South Africa and Swaziland, exploring educational structures and practices critically and whether they manifest various commitments to change, or more specifically (in)justice.

The first article by Torres and Quaresma calls into question the socialisation of neoliberal academic excellence, achievement and success within a Portuguese educational context. This exploratory study presents an analysis of academic rituals and students' socialisation to performativity in a backdrop of globally intensified neoliberal policies within education. In their effort to understand the links between Portuguese educational policies and family and community pressures to attain educational success, 
Torres and Quaresma call attention to the origins, contentions and compromises of the many meanings of such success. Introducing influential models of meritocracy from the United States, United Kingdom and France, the authors interrogate the dynamics between democracy and meritocracy across select Portuguese public secondary schools, paying special attention to what the authors term the "ritual" of academic distinction. The authors argue that these globalised neoliberal forces of the 1980s also penetrated the Portuguese public education system, particularly reinforcing notions of individualism, elitism and exclusion through systems and structures that promote competition and hierarchy. However, the authors reveal that differences in how assessment and distinction are implemented within these countries and the Portuguese context in particular vary across institutions. These "ritualised" practices of meritocracy practised within schools, they find, have varying socialising effects on the reputations and mobility of young students within and far beyond formal education.

In "A Modest Critical Pedagogy for English as a Foreign Language Education", Kim and Pollard explain how a critical pedagogy approach to teaching and learning benefits a curriculum steadfast in countering the asymmetrical power imbalance between students and teachers. The authors adapt a Foucauldian framework to advocate for a new form of critical pedagogy that is critical of itself within a South Korean higher education context. Kim's experience as an English language instructor at a South Korean university (a previous study upon which this paper is based [Kim 2015]) revealed a significant gap between the understanding and practice of critical pedagogy in the classroom. Although critical pedagogy has its advantages, it also has its limitations. Analysing a case study of a Korean English as a Foreign Language course, Kim and Pollard explore how teaching and learning are challenged in the classroom. Critical pedagogy, the authors found, must also be relevant - not only learner- or student-centred. Interrogating the challenges and discomforts experienced by instructors and students alike after critical pedagogical practices were introduced in an English as a foreign language course, the authors seek to promote a pedagogical approach that is also self-critical in order to maintain relevance. Kim and Pollard, therefore, remind us that being critical in teaching and learning is insufficient and also problematic to some extent; it is equally - if not more - important to ensure the pedagogy is localised, as well as emancipatory in scope. Therefore, the authors reveal that critical pedagogy itself must be turned upside-down and inside-out, and this begins with the rooted critical theory itself.

Prats, Deusdad and Cabre introduce the effects of the migration influx into Europe, which was further exacerbated by economic factors over the last two decades, shaping an ethnic diversity that also surfaces in the education system. More specifically, Prats et al. discuss the xenophobic attitudes and stereotypes among students and how teachers respond to them at a secondary school in Spain. Focusing specifically on peer groups formed among 15- and 16-year-old students, the authors assess to what extent such stereotypes and other racist and xenophobic attitudes persist within and between peer groups, which racial or ethnic groups in particular are most stigmatised by specific peer 
groups, what particular factors influence such prejudicial attitudes amongst students in the first place, and lastly, how teachers' own attitudes and behaviours perpetuate and/ or respond to such prejudices. As in many other countries and regions of the global North, especially across Europe, the sociopolitical climate in Spain is characterised by being unfavourable towards immigrants, Muslims, and Roma populations in particular, among others.

Responding to recent protests among students for the "decolonisation" of higher education, Vortser and Quinn advocate for academic staff, and more specifically with the support of academic developers, to take on a "decolonial turn" within South African higher education through staff development programmes. Relying upon Margaret Archer's realist social theory that cross-examines the interactions between structure and agency, the authors analyse the "macro cultural and structural conditions" of the higher education landscape to reflect upon and challenge their own practices and understandings as academic developers. Through their critical analyses of contemporary discourses regarding the transformation of higher education and decolonisation of South African universities, Vorster and Quinn reflect upon recent student demands for "decolonisation" as a substitute or replacement for "transformation". The authors also examine how agency should be applied within the current university structure in their own roles as academic developers.

Similarly, Botha analyses problematic educational structures through organisational change processes at a secondary school in South Africa in a continuing study. Applying an interventionist research methodology called a "Change Laboratory", which is framed by Vygotsky's cultural-historical activity theory (CHAT), the author seeks to explore how school staff - management and teachers - can transform their own praxes in promoting a "bottom-up" approach in order to challenge adopted hegemonic knowledge production. By applying the principles of CHAT, Botha argues that staff can develop the "theoretical and practical tools necessary for managing change" at a South African secondary school. In this study, the author poses a challenge to current knowledgebased traditions and practices and also suggests a critical introspection of approaches to research that target and problematise educational practitioners rather than understanding their transformative capacities.

The next two articles explore the ways in which application and education of the arts have the capacity to open up discourses and visualisations of perceptions and attitudes of racialised and additional "othered" identities. The studies also reveal how art expressions can respond to, as well as preserve these same fracturing beliefs and understandings.

Alexander and Costandius's article is central in problematising educators' attitudes and perceptions regarding human colour and complexionism as understood through arts-inspired pedagogy. Through a transliteration of a crayon colour called menskleur ("human colour") in Afrikaans, Alexander and Costandius use art to examine the symbolic and actualised manifestations of the meaning of skin colour, 
especially of racialised perceptions and understandings among primary students in two former "Model-C" schools in the Western Cape of South Africa. Through analysis of conversations and art projects, the authors explore various ways in which the topic of racial identity is manifested within Grade 3 art classrooms. The authors' motivations behind this study were to promote critical engagement with topics and issues related to race and skin colour. Alexander and Costandius's study of Grade 3 learners' attitudes and perceptions of race and skin colour reveals that much more needs to be explored in conversations and socialisations about racialised beliefs, especially among children. The authors illuminate that the arts can be a creative and innovative tool in discussing the "difficulty" of race.

Shifting the study and application of arts to a higher education institution, Biscombe, Conradie, Costandius and Alexander examine the phenomenon of "othered" identities at a visual arts department at a South African university. The authors apply an integration of theories on othering: symbolic racism, power and violence; the racialised body; and "othering" via the visual arts to frame their analyses of "othering" via racial, linguistic and economic differentiations and distancing. This work portrays a description of visual hegemony fashioned through the strategic interplay of both symbolic racism and symbolic violence. The conception of the "other" presented here represents the marginalisation, exclusion and discomfort in the production of art through a racialised, privileged lens. Biscombe et al. ask us to revisit the popular assumption that arts-based programmes and departments provide "safe" spaces for free expression, calling into question how institutional structures and systems influence "othering" discourses even within "unlikely" spaces of creative expression. Recognition of the university's historical and social ecology contributes to the authors' understandings of the deeplyrooted and entrenched philosophies and ideologies that present challenges to addressing and overcoming "othering" discursive frames.

The last two articles in this issue underscore the necessity of the education of vulnerable, marginalised children. Most importantly, the authors present alternative, non-traditional approaches to empowering, liberating and transforming the experiences of children through what is seemingly presented as a form of critical resistance education.

In their study of six Grade 6 vulnerable children at a rural primary school in Swaziland, Motsa and Morojele present "narratives of resilience" through a variety of qualitative research methods, including the innovative tool of photo voice. Providing an in-depth landscape of the socioeconomic inequalities and inequities vulnerable school-aged children are susceptible to and threatened by, the authors still maintain the placement of resilience at the centre of their work, granting agency to the children in the study, who serve in the capacity of "co-researchers", challenging the dominant westernised norms of research relationships that define researcher-subject/object. Motsa and Morojele identified key themes that comprise the core elements of resilience recognised in the six children who participated with them in this study, particularly "agency and perseverance" in response to challenges of solitude, isolation and abusive teachers in the classroom. The authors raise important questions, especially with regards 
to the gaps and accountabilities of education ministries, schools and educators in genuinely understanding and responding to the needs of vulnerable children.

Similarly, Kim focuses on empowerment and transformation from vulnerability of schoolchildren. Utilising Amartya Sen's capability approach, Kim highlights a case study on a church-based community school serving children in poverty in South Korea. Though the application of critical communicative methodology, Kim explores how the learning and teaching of vulnerable children within a community is shaped by the capability approach. Additionally, the role of this particular approach regarding means of improving educational equality and issues of child poverty is also analysed. Backgrounds of education and family and child poverty in South Korea provide meaningful contexts in understanding how the capability approach can be both challenging and fruitful for all stakeholders involved within and beyond the community school environment. Emphasis on transformation out of vulnerability and achieving equality are the main motivations in the application of the capability approach.

Lastly, Elena Toukan's review of Joel Weistheimer's What Kind of Citizen?: Educating Our Children for the Common Good offers a number of thought-provoking insights into and analyses of Westheimer's exploration of how schools develop and foster citizenship education and what "citizen" means within an educational context.

\section{REFERENCES}

Althusser, L. 1992. The Future Lasts a Long Time. New York: New Press.

Boltanski, L. 2013. On Critique: A Sociology of Emancipation. Hoboken: John Wiley and Sons.

Deacon, R., R. Osman, and M. Buchler. 2009. Audit and Interpretative Analysis of Education Research in South Africa: What Have We Learnt? Pretoria: NRF.

Escobar, A. 2007. "Worlds and Knowledges Otherwise.” Cultural Studies 21 (2): 197-210.

Keet, A. 2014. "Epistemic 'Othering' and the Decolonization of Knowledge.” Africa Insight 44 (1): 23-37.

Keet, A. 2016. "The Perfect Crime Reloaded: Racism's Knowledge, Diversity and Scholarship in Higher Education." Keynote Address, International Colloquium on Higher Education and Diversity, University of California, Los Angeles, February 5, 2016.

Kim, M. K. 2015. 'Students' and Teacher's Reflections on Project-Oriented Learning: A Critical Pedagogy for Korean ELT.” English Teaching 70 (3): 73-98.

Maldonado-Torres, N. 2007. "On the Coloniality of Being: Contributions to the Development of a Concept." Cultural Studies 21 (2): 240-70.

Marx, K. 1844. "Letter from Marx to Arnold Ruge in Dresden." https://www.marxists.org/archive/marx/ works/1843/letters/43_09-alt.htm (accessed May 17, 2017). 
Mignolo, W. 2013. “(De) Coloniality and Uneasy (Post) Colonialism.” https://globalstudies.trinity.duke. edu/volume-3-dossier-3-uneasy-postcolonialisms (accessed May 13, 2017).

National Research Foundation (NRF). 2009. "Status Quo Study of Education Research in South Africa. Education and the Challenges for Change 2003-2006." Report compiled by L. Holtman and researchers from the University of the Western Cape. Pretoria: NRF.

Tuck, E., and K. W. Yang. 2012. "Decolonization Is Not a Metaphor." Decolonization: Indigeneity, Education and Society 1 (1): 1-40. 